\title{
The 2015 Sexual Offences Amendment Act: Laudable amendments in line with the Teddy Bear clinic case
}

\author{
P Mahery, LLB, LLM \\ Oliver Schreiner School of Law, University of the Witwatersrand, Johannesburg, South Africa
}

Corresponding author: PMahery (prinslean.mahery@wits.ac.za)

\begin{abstract}
Two years ago the Constitutional Court invalidated provisions in the Sexual Offences Act which outlawed sexual conduct between adolescents. Parliament was ordered to fix the relevant provisions and to decriminalise consensual sexual activity between adolescents. In July 2015 the Amendment Act came into operation with the aim of revising the current Sexual Offences Act in line with the Constitutional Court judgment. This article evaluates some of the changes contained in the Amendment Act to determine its alignment with the ruling of the Constitutional Court. It also considers how the changes will impact the reporting obligations of health providers.
\end{abstract}

SAfr J BL 2015;8(2):4-6. DOI:10.7196/SAJBL.375

In October 2013 the Constitutional Court (CC) declared provisions of the Sexual Offences Act (herein after referred to as the principle Act, also abbreviated as SOA) unconstitutional and invalid. The sections were invalidated because they allowed adolescents (i.e. 12 - 15-yearolds) to be prosecuted for engaging in consensual sexual activity with other adolescents. ${ }^{[1]}$ The order of invalidity was suspended, parliament was given time to rectify the defects of the law and a moratorium was placed on reporting sexual acts between consenting adolescents. The process of drafting and enacting the Amendment Act was hastened by the strict deadline of 18 months that was initially given to parliament by the CC to finalise the amended law. ${ }^{[1]}$ Just over a year after the CC judgment, the Minister of Justice and Correctional Services published an Amendment Bill for public comment. ${ }^{[2]}$ Public hearings took place over a period of about five months until March 2015. Unable to comply with the initial deadline created by the CC the Speaker of Parliament applied for more time to finalise the law and in May 2015 the CC granted parliament until August 2015 to put the amended law in place. ${ }^{[3]}$ The Bill was debated and approved by majority vote in Parliament by June 2015 and was subsequently signed into law on 3 July 2015. Its full title is the Criminal Law (Sexual Offences and Related Matters) Amendment Act Amendment Act ${ }^{[4]}$ (herein after simply referred to as the Amendment Act).

The consequences of the original $\mathrm{CC}$ judgment for health providers were outlined in this publication ${ }^{[5]}$ and others publications. ${ }^{[6]}$ Suffice to say that the declaration of invalidity and the moratorium served as a means of giving effect to the health and other important rights of adolescents (e.g. their right to privacy and physical integrity). ${ }^{[7]}$ It also operated in support of provisions of other laws, particularly the Children's Act ${ }^{[8]}$ which, for example, allows children aged 12 and older to access contraceptives. However, the suspended order and moratorium were only temporary solutions to the negative effects of the provisions in the principal Act and a more permanent solution in the form of legislation is welcomed.
This article aims to compare and analyse the new provisions against the invalidated sections of the SOA through commentary in order to determine if the amendments are in line with the CC judgment. The Amendment Act makes four significant changes to the provisions of the SOA that are relevant to the discussion here. This article will focus only on those specific amendments.

\section{Analysis of the amendments contained in the Amendment Act \\ Amendment No. 1}

Section 1 of the principal Act had two different definitions of a child. Firstly a child was defined as a person under the age of 18 and secondly, for the purpose of sections 15 and 16, a child was considered a person older than 12 but younger than 16 (i.e. between 12 and 15). The Amendment Act removes the second definition and creates one overall definition of a child as a person under the age of 18 . Furthermore the legislature amended sections 15 and 16 (discussed below) by directly inserting certain age requirements regarding children engaging in sexual conduct.

\section{Comments}

The SOA is not the easiest piece of legislation to read. This amendment will reduce any confusion on the concept of a child for the purpose of the SOA. By inserting the age requirements directly into the relevant sections 15 and 16 the lawmakers would make those sections easier for professionals like health providers to read, understand and apply.

\section{Amendments 2 and 3: Relating to sections 15 and 16 of the SOA respectively}

The Preamble of the Amendment Act makes it clear that the Sexual Offences Act is amended 'so as to ensure that children of certain ages are not held criminally liable for engaging in consensual sexual acts with each other... ${ }^{[4]}$ So the amendment is directed specifically at sections 15 and 16 of the SOA. In its original form section 15 outlawed sex with a child between 12 and 15 years of age, even if it was consensual. The effect of this was that even if the two children, 
who are engaged in sexual activity, were both adolescents they were both guilty of contravening section 15 . Similarly section 16 originally outlawed sexual violations (i.e sexual acts not involving penetration) committed between children $12-15$ years of age, even if it was consensual.

As indicated previously, in the Amendment Act the legislature chose to remove the consenting age setting from the definition of a child and to reinsert it directly into the amended sections 15 and 16. The amendment now reads that anyone who commits sexual penetration or sexual violation with a child 'who is 12 years of age or older but under the age of 16 years' (i.e. adolescents aged $12-15$ ) is guilty of an offence even if the adolescent consents to such an act. So the broad prohibitions originally contained in sections 15 and 16 are retained in the Amendment Act. However, two exceptions are included in the Amendment Act to limit the general prohibition. In the first instance (the second exception relates to amendment No. 4 discussed below) the Amendment Act goes on to say that there would be no offence if, at the time of the sexual act, the perpetrator is also an adolescent (i.e. when both parties are adolescents).

\section{Comments}

The CC finding made it clear that adolescents should not be criminalised for engaging in consensual sexual acts. The Amendment Act clearly removes that criminalisation while still maintaining the prohibition of other perpetrators to engage in sexual acts with adolescents. This amendment is therefore clearly in line with the CC judgment.

\section{Amendment No. 4}

Originally section 56(2)(b) of the SOA created an age-gap defence for a perpetrator who was 16- or 17-years-old at the time of committing a sexual violation against (with) a consenting adolescent who was more than two years younger than the perpetrator. The Amendment Act makes fundamental changes to the position of the 16- and 17-year-old in this regard. The Amendment Act states that there would be no sexual offence committed if, at the time of the sexual act in question, the perpetrator is 16 or 17 years of age and the age difference between the perpetrator and the victim is no more than two years. Furthermore, in the event of the perpetrator being 16 or 17 and there is more than a 2-year age difference the Director of Public Prosecution must authorise the institution of a prosecution. To this end the Amendment Act subsequently removed the original age-gap defence that was set out in section 56(2) (b) of the SOA.

\section{Comments}

Firstly, what is significant here is that the defence created in terms of the now removed section 56(2) (b) applied only in respect of a sexual violation and not sexual penetration. However, the amendment now covers both sexual penetrations and sexual violations. The amendment is therefore broader than the original provision. The second significant change created by the Amendment Act is that it replaces the original age-gap defence with an age-gap 'exception' to the offence. The difference is significant. When section 56(2)(b) was applied it meant that if a 16- or 17-year-old engaged in sexual activity with an adolescent, and the age difference between the parties was less than two years, then an offence was still committed by the older child and the prosecutor could still decide to prosecute. If the prosecutor decided to charge and prosecute the 16- or 17-year-old then the child perpetrator would be able to raise the age gap defence to get acquitted. The defence did not serve as an automatic get-outof-jail-free card, it had to be argued in court and it was up to the court to decide whether the defence would succeed or not. However, the amendment works differently. By removing the age-gap defence it now means that if one child is 16- or 17-years-old and his consensual sexual partner is an adolescent who is not more than two years younger, then no offence has been committed at all. No prosecution will lie against the 16- or 17-year-old. Such a child cannot be charged because there is no offence.

\section{What does it mean now that the Amendment Act has become law?}

The Amendment has a knock-on effect on section 54 of the SOA, which is the compulsory reporting section, obligating professionals like health providers to report sexual offences. Firstly, it is no longer regarded as an offence for adolescents to engage in consensual sexual activity with other adolescents. This means that a mature 12-yearold who seeks contraceptives in accordance with the Children's Act and who is knowingly engaged in consensual sexual activity with another child between 12 and 15 years of age is no longer at risk of being reported and prosecuted in terms of the SOA. Therefore health providers do not have to report such cases in terms of section 54 of the SOA. The health provider consulting with a 12-year-old patient is similarly no longer at risk of prosecution for failing to report knowledge of the sexual acts of this particular patient.

It is important to note that the effect of the amendments does not mean that the lawmakers have lowered the age of consent to sex to 12 years. The age of sexual consent is still 16. However, the amendment creates an exception to the offences so as not to catch adolescents in the net of a prohibition which is generally aimed at protecting children against adult perpetrators. This would be in accordance with the CC order.

The lawmakers have effectively changed the legal position around 16- and 17-year-olds. The SOA required that a 16- and 17-year-old who engaged in sexual activity with an adolescent be reported (whether they committed sexual penetration or a sexual violation). It was up to the prosecutor to decide whether or not to prosecute and they would have had to take into account the age-gap defence (in respect of a sexual violation only) in that decision. However, in terms of the new amendments the 16- and 17-year-old need only be reported if he or she engaged in sexual activity with an adolescent who is more than two years younger (whether it was an act of sexual penetration or a sexual violation). What this means is that, for example, a 17-yearold who has consensual sex with a 13-year-old and impregnates her commits an offence because there is more than two years age gap between these parties. The 17-year-old must be reported for committing a sexual offence if the health worker becomes aware of this. However, if a 16-year-old impregnates a 15 -year-old as a result of consensual intercourse then the 16-year-old has not committed an offence at all (in terms of the exception created by the Amendment) and no report is required.

There are areas of the sexual offences law that the Amendment Act does not attempt to change. The reporting obligations are not directly addressed by the Amendment Act and will continue to operate as it is currently set out in the SOA. The differential treatment 
between 16- and 17-year-olds and adolescents was not an issue dealt with by the CC so the legislature has also left that divide between categories of children intact in the Amendment Act. The CC made it clear that the law must fulfil its primary function, which is to protect children from adult predators and that is why they suspended the order of invalidity. In response the lawmaker has kept the general prohibition against adults intact so if the health provider is aware of a child patient engaged in sexual activity with an adult ( 18 years or older) that adult has still committed a criminal offence that will have to be reported. Despite changing the legal position of the adolescent the Amendment Act does not seek to change the position in the principal Act that if anyone (including an adolescent) engages in sexual activity with a child below 12 years of age, it constitutes an offence which requires reporting.

\section{Conclusion}

The CC judgment has been commended for protecting children's rights. ${ }^{[9]}$ The task of the lawmakers was to ensure that they drafted a law in line with the CC judgment. These new SOA amendments received much support from various civil society organisations when they were being discussed during the public hearings. ${ }^{[10]}$ The drafters of this Amendment Act would therefore be commended for effectively decriminalising sexual activity between adolescents in accordance with the CC judgment. It would get additional praise for proactively improving the position of the 16- and 17-year-old who is engaged in consensual sexual conduct with an adolescent by limiting the offence and reporting obligation to when the adolescent is more than two years younger than the 16- or 17-year-old. This amendment could certainly be said to have gone beyond the scope of the order made by $\mathrm{CC}$ but should further operate to create less intrusion into the sexual autonomy of the consenting adolescent while at the same time still maintaining an avenue for prosecution - if the much older child unduly influences the much younger adolescent to engage in sexual acts.

\section{References}

1. Teddy Bear Clinic for Abused Children and Another v Minister of Justice and Constitutional Development and Another 2014(2) SA 168 (CC).

2. Republic of South Africa. Criminal Law (Sexual Offences and Related Matters) Amendment ActAmendment Bill. [B18-2014].Pretoria:GovernmentPrinter, 2014.http:// www.parliament.gov.za/live/commonrepository/Processed/20150302/594925_1.pdf (accessed 5 August 2015).

3. Acting Speaker of the National Assembly v Teddy Bear Clinic for Abused Children and Another [2015] ZACC 16

4. Republic of South Africa. Criminal Law (Sexual Offences and Related Matters) Amendment Act Amendment Act 5. Government Gazette no. 389772015. Pretoria: Government Printer, 2015.

5. Mahery P. Reporting sexual offences involving child patients: What is the current law following the Constitutional Court judgment? S Afr J BL 2014;7(1):26-29. [http://dx.doi.org/10.7196/sajbl.303]

6. McQuoid-Mason D. The Teddy Bear Clinic Constitutional Court case: Sexual conduct between adolescents consenting children aged under 16 years decriminalised and a moratorium on the reporting duties of doctors and others. S Afr Med J 2014;104(4):275-276.

7. Republic of South Africa. Constitution of the Republic of South Africa, Sections 12 and 13 of 1996. Pretoria: Government Printer 1996

8. Republic of South Africa. Children's Act No. 38 of 2005. Pretoria: Government Printer 2005.

9. Buthelezi MC, Bernard RB. The court knows the law. J S Afr Law 2014;3:625-639.

10. Community Law Centre, University of the Western Cape and Centre for Justice and Crime Prevention. Submission to the Portfolio Committee on Justice and Correctional Services on the Criminal Law (Sexual Offences and Related Matters) Amendment Act Amendment Bill 3. Cape Town: University of the Western Cape. 2015. Pretoria: Government Printer 2015. 